\title{
Occurrence of Avian Mycoplasmas in Free-Living Muscovy-Ducks (Cairina Moschata)
}

\begin{abstract}
Euthor(s)
Magalhães BSN' (iD https://orcid.org/0000-0001-7814-853X

Pereira VLA" (iD) https://orcid.org/0000-0003-2197-8916

Machado LS" (iD https://orcid.org/0000-0003-4117-195X

Dias TS" (iD) https://orcid.org/0000-0001-8815-3316

Balthazar DA III (iD) https://orcid.org/0000-0002-9641-0674

Barreto MLIV (D) https://orcid.org/0000-0002-1725-1995

Troccoli Fv (iD https://orcid.org/0000-0001-9461-9194

Cunha NC.,II (iD https://orcid.org/0000-0003-0582-5098

Nascimento ER" (iD https://orcid.org/0000-0003-2316-8933

Almeida FM' (iD) https://orcid.org/0000-0002-8152-5057

Almosny NR' (D) https://orcid.org/0000-0001-7043-0717

Programa de Pós-Graduação em Medicina Veterinária (Clínica e Reprodução Animal), Faculdade de Veterinária, Universidade Federal Fluminense (UFF);

" Departamento de Saúde Coletiva Veterinária e Saúde Pública, Faculdade de Veterinária, Universidade Federal Fluminense (UFF)

III Departamento de Medicina e Cirurgia Veterinária, Instituto de Veterinária (IV), Universidade Federal Rural do Rio de Janeiro (UFRRJ)

Iv Departamento de Imunobiologia, Instituto de Biologia, Universidade Federal Fluminense (UFF)

Fundação Zoológico do Rio de Janeiro.
\end{abstract}

\section{-Mail Address}

Corresponding author e-mail address Thomas Salles Dias

Rua Vital Brasil Filho, 64 - Niteroi, Rio de Janeiro, Brasil. Zip code: 24230340

Phone: (5521) 99761-1993

Email: thomassalles@id.uff.br

\section{-Keywords}

Anseriformes, free-living, Mollicute Class, Muscovy-ducks, mycoplasmosis.

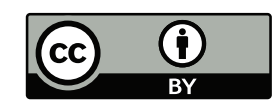

Submitted: 08/July/2020

Approved: 15/September/2020

\section{ABSTRACT}

The present study aimed to investigate, by culture and PCR, the occurrence of Mollicutes, Mycoplasma gallisepticum and Mycoplasma synoviae in free-living Muscovy-ducks (Cairina moschata) from the Rio Zoo, RJ, Brazil. Tracheal swabs were obtained from 82 asymptomatic ducks and the samples were submitted to culture of mycoplasmas and PCR for identification of Mollicutes Class, Mycoplasma gallisepticum (MG) and Mycoplasma synoviae (MS). Samples were also analyzed directly by PCR, without prior culture, for Mollicutes, MG and MS. Eighteen (18/82) Muscovy-ducks were positive for Mollicutes by culture, all isolates were confirmed as Mollicutes and seven were identified as MG. Of the samples analyzed directly by PCR, without prior culture, 17,1\% (14/82) was positive for Mollicutes, being 35,7\% (5/14) identified as MG and $21,4 \%(3 / 14)$ as MS. The occurrence of Mollicutes class bacteria was detected in Muscovy-ducks. MG and MS were identified in these animals suggesting the circulation of these agents in the Rio de Janeiro Zoo and may present a risk for the health status of the other birds.

\section{INTRODUCTION}

Mycoplasmas are the smallest known prokaryotes, that can cause acute or chronic diseases, lacking cell wall, colonies usually have a characteristic "fried-egg" appearance and transmission may occur horizontally or vertically (Razin et al., 1998). The clinical signs commonly observed in wild birds are cough, sneezing, rales, eye and nasal discharges and conjunctivitis (Nascimento et al., 2005b). M. gallisepticum (MG) and $M$. synoviae (MS) are the main species of mycoplasmas, causing an economic impact due to the decrease of egg production and egg quality, poor hatchability, high rate of embryonic mortality and culling of dayold birds, increase in mortality and medication costs (Nascimento et al., 2005b) therefore mycoplasmosis can represent an important disease in the rearing and breeding of wild birds (Gomes et al., 2010).

Mycoplasmas have been isolated from domestic (Ivanics et al., 1988) and wild ducks (Goldberg et al., 1995) although M. gallisepticum and M. synoviae causes no clinical signs in infected ducks (Bencina et al., 1988) so these ducks are able to silently spread mycoplasma and may play an important role as a reservoir of pathogenic mycoplasmas. To our knowledge there is no report of MG or MS in free-living Muscovy-ducks. At the Rio Zoo it was possible to observe a population of free-living Muscovy-ducks (Cairina moschata moschata) crossbreed with domestic ducks (Cairina moschata domestica). This crossing generated multiples birds with high flight and reproduction capacity that are distributed throughout the zoo area, with possibility to fly inside and outside the zoo premises, thus having direct contact with other free birds, such as doves, sparrows and, pigeons and also birds from the zoo collection, 
Magalhães BSN, Pereira VLA,

Machado LS, Dias TS, Balthazar DA

Barreto ML, Troccoli F, Cunha NC,

Nascimento ER, Almeida FM, Almosny NR
Occurrence of Avian Mycoplasmas in Free-Living Muscovy-Ducks (Cairina Moschata) as well as with employees and visitors of the park. The Muscovy-ducks (Cairina moschata) belongs to the Order Anseriformes, Family Anatidae, and is widely distributed from Mexico to southern South America. Muscovy-ducks have a high reproductive potential and escaped or intentionally introduced populations can establish themselves in urban and suburban environments (Downs et al., 2017). The presence of these birds in urban/suburban areas may be a risk for transmission of diseases to other birds (Solomon et al., 2012). The present study aimed to investigate, by culture and PCR, the occurrence of Mollicutes, Mycoplasma gallisepticum, and Mycoplasma synoviae in free-living muscov-ducks from the Rio Zoo, RJ, Brazil.

\section{MATERIAL AND METHODS}

This study was approved under no. 1017 by "Comissão de Ética no Uso de Animais" (CEUA) of "Universidade Federal Fluminense" and by "Sistema de Autorização e Informação em Biodiversidade" (SISBIO-ICMBio) under number 59538-1. In addition, the project was registered in "Sistema Nacional de Gestão do Patrimônio Genético e do Conhecimento Tradicional Associado" (SISGEN), no. A4E34FC.

In this study the whole population of free-living Muscovy-ducks ( $n=82$ ) (C. moschata), from the Rio de Janeiro Zoo, Brazil $\left(S 22^{\circ} 54^{\prime} \mathrm{W} 43^{\circ} 13^{\prime}\right)$, regardless of gender or age were analyzed. They lived in fairly small groups spread across the Rio Zoo, with the possibility to fly inside and outside the zoo area. The animals were captured and manually restrained, identified with foot rings at the time of collection and tracheal swabs were collected, conditioned in microtubes containing modified Frey's liquid medium (Nascimento \& Pereira, 2009) and kept refrigerated until the processing. All the ducks were clinically examined and showed no clinical signs of disease.

An aliquot of $0.2 \mathrm{~mL}$ of the collected sample was inoculated into $1.8 \mathrm{~mL}$ of the modified Frey liquid medium (Himedia, India). Serial dilutions were made until $10^{-5}$, and the dilutions $10^{-3}$ and $10^{-5}$ were spread on plates containing modified Frey solid medium (Himedia, India) (Nascimento \& Pereira, 2009). All samples were incubated at $37^{\circ} \mathrm{C}$ under microaerophilic and observed for 21 days under a 100x magnification stereoscopic microscope (Razin et al., 1998). For molecular detection, a $0.5 \mathrm{~mL}$ aliquot of the collected sample was submitted to DNA extraction by the phenol-chloroform adapted method (Sambrook \& Russell, 2006). DNA amount and quality determination was performed in BiodropTouch ${ }^{\circledR}$ (Biochrom, Harvard
Bioscience, EUA) with subsequent PCR for the detection of Mollicutes class, MG, and MS according to Uphoff \& Drexler (2002), Nascimento et al. (2005a) and Lauerman et al. (1993) respectively. The PCR for detection of Mollicutes was performed containing 1X PCR buffer $(10 \mathrm{mM}$ Tris- $\mathrm{HCl}, \mathrm{pH} 8.0$ and $50 \mathrm{mM}$ of $\mathrm{KCl}), 2.0 \mathrm{mM}$ of $\mathrm{MgCl}_{2}, 0.8 \mathrm{mM}$ of dNTP, $1 \mathrm{U}$ of Taq Polymerase (Ludwig, Brazil), $0.6 \mu \mathrm{M}$ of each primer (Invitrogen, Brazil) and $5 \mu \mathrm{L}$ of DNA. For MG detection the reaction contained: $1 X P C R$ buffer $(10 \mathrm{mM}$ Tris- $\mathrm{HCl}$, $\mathrm{pH} 8.0$ and $50 \mathrm{mM}$ of $\mathrm{KCl}), 2 \mathrm{mM} \mathrm{MgCl}, 0.2 \mathrm{mM}$ dNTP, $1 \cup$ Taq Polymerase (Ludwig, Brazil), $0.2 \mathrm{nmol}$ of each specific primer (Invitrogen, Brazil), and $2 \mu \mathrm{L}$ of DNA. MS reaction contained $1 X \mathrm{PCR}$ buffer $(10 \mathrm{mM}$ Tris- $\mathrm{HCl}$, pH 8.0 and $50 \mathrm{mM} \mathrm{KCl}), 1.5 \mathrm{mM} \mathrm{MgCl} 2 ; 0.2 \mathrm{mM}$ of dNTP, $0.2 \mathrm{nmol}$ of each specific primer (Invitrogen, Brazil) and $2 \mu \mathrm{L}$ of DNA. All reactions were performed in PTC $-100^{\circledR}$ thermocycler (Bio-Rad Laboratories, England) with a final volume of $25 \mu \mathrm{L}$. The MS ATCC 25204 and MG ATCC 129 S6 strains were used as positive controls and as ultrapure water negative control. The amplicons obtained in PCR were separated in 1.5\% agarose gel, submerged in Tris-Borate-EDTA Buffer (TBE), and then submitted to electrophoretic run at $94 \mathrm{~V}$ for 40 minutes. Following the electrophoretic run, the gel was stained with ethidium bromide, and visualization of the amplicons was done under ultraviolet light in a transilluminator and the image captured for photodocumentation.

Cohen's kappa (к) test was performed to estimate the degree of concordance between PCR and culture.

\section{RESULTS AND DISCUSSION}

Among the 82 Muscovy-ducks evaluated in this study $21.9 \%$ (18/82) were positive for Molicuttes by culture method. Of these isolates all were confirmed as Mollicutes by PCR and 38.9\% (7/18) as M. gallisepticum and $M$. synoviae was not detected. The culture of MS is more difficult when compare to other mycoplasmas (Elhamnia et al., 2010), and the other mycoplasmas can inhibit MS growth producing false-negative results in the culture. In samples analyzed directly by PCR, without prior isolation, $17.1 \%$ (14/82) was positive for Mollicutes, being 35.7\% (5/14) identified as MG and $21.4 \%$ (3/14) as MS. Avian mycoplasmosis can be diagnosed by isolation and PCR, and tracheal and choanal fissure swabs are excellent samples for these techniques, being widely used to diagnose or monitor MG and MS in birds (Umar et al., 2017). In our study it was possible to identify more positive samples for Mollicutes by isolation than by $P C R$, although this 
Magalhães BSN, Pereira VLA,

Machado LS, Dias TS, Balthazar DA

Barreto ML, Troccoli F, Cunha NC,

Nascimento ER, Almeida FM, Almosny NR
Occurrence of Avian Mycoplasmas in Free-Living Muscovy-Ducks (Cairina Moschata) technique is considered to be more rapid, sensitive, and specific. The agreement between culture and PCR was almost perfect $(\kappa=0.8453)$ and combination of these techniques are recommended to increase the probability of mycoplasmas detection. Our study differs from Timenetsky et al. (2006) which detected more infected samples by PCR than the culture, but five positive cultures were not confirmed by $P C R$ for Mollicutes, and their identification was only possible by specific PCR. Difference in culture and PCR results can be explained by the number of mycoplasmas in the sample, occurrence of inhibitors or failure in the diagnostic method (Timenetsky et al., 2006).

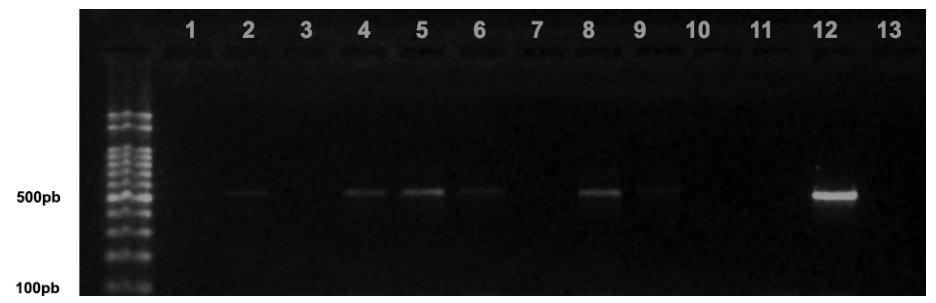

Figure 1 - Ethidium bromide-stained agarose gel of Mycoplasma spp. PCR products revealing a 500bp amplicon in Cairina moschata traqueal swabs. First lane (left to right) 100bp molecular weight marker; Number 12 positive control with a 500bp amplicon Number 13 negative control - Numbers 2, 4,5,6, 8 and 9 positive field samples; Numbers 1,3, 7 and 11 negative field samples.

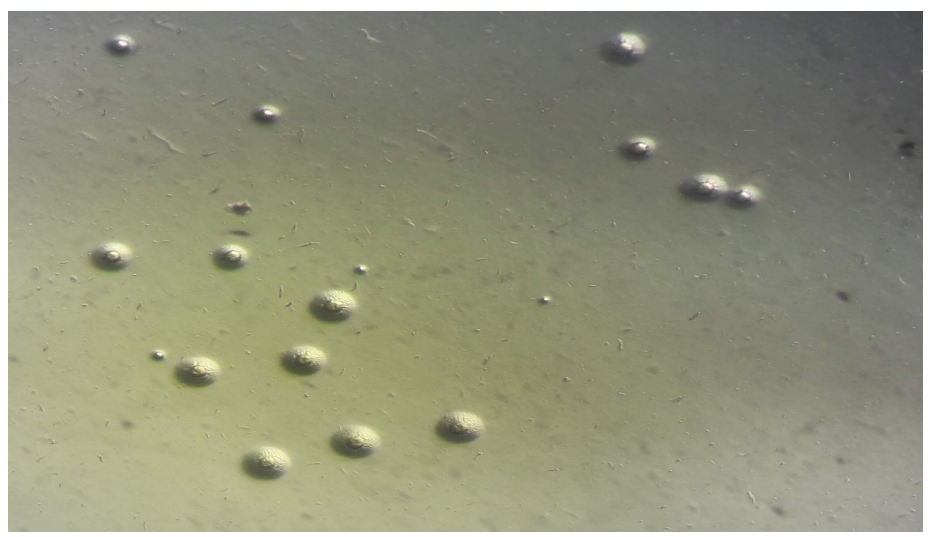

Figure 2 - Mycoplasma spp. from Cairina moschata traqueal swabs on solid modified Frey medium. Visualization under stereomicroscope (100X).

The presence of mycoplasmas in asymptomatic wild captive birds has already been reported in the study by Silva et al. (2016) who observed a prevalence of $16.5 \%$ Mycoplasma spp. in 85 parrots and Carvalho et al. (2017) who found percentages of $21.6 \%, 15.7 \%$ and $6.7 \%$ positivity in birds from, respectively, a Wild Animal Sorting Center, a commercial breeding site and a conservation breeding site and these results agree with what was found in our study. The presence of these free-living ducks close to captive birds in the zoo can pose a risk to health of susceptible birds and to species in recovery programs, since there is a possibility that Muscovy ducks are acting as reservoir of pathogenic mycoplasmas.
Several ducks in our study were positive for MG and MS and, lived spread across the Rio Zoo, and according to Nascimento \& Pereira (2009), the presence of mycoplasmas in wild birds can favor the maintenance of this agent in the environments by the presence of birds with clinical disease or inapparent infection. MG and MS circulation in asymptomatic birds was also found in a study by Carvalho et al. (2017) which detected positivity of $34.15 \%$ for MG and $7.32 \%$ for MS in 14 species of parrots positive for Mycoplasma spp. Michiels et al. (2016) conducted a study of the prevalence of MG and MS in commercial birds, homing pigeons and wild birds in Belgium and concluded that wild birds probably play a limited role as a reservoir, but cannot be excluded with a possible impact on the transmission of mycoplasmas. Therefore, studies like ours are important to understand the epidemiological dynamics of avian mycoplasmas and how they are distributed among bird species.

Mollicutes, M. gallisepticum, M. synoviae were detected in Muscovy-ducks (Cairina moschata), suggesting the circulation of these agents in the Rio de Janeiro Zoo. Due to the possibility of flying and walking across the zoo these Muscovy-ducks can play a role as reservoirs and disseminators of pathogenic mycoplasmas and can represent a risk for other birds. Further studies should be carried out on the dissemination of mycoplasmas in these birds for the epidemiological analysis of these bacteria, assessment of the possible interference in the health of birds inside and out of Rio Zoo.

\section{DECLARATION OF COMPETING INTERESTS}

The authors declare no competing financial interests or conflicts.

\section{ACKNOWLEDGMENTS}

This study was partially financed by the "Coordenação de Aperfeiçoamento de Pessoal de Nível Superior" - Brasil (CAPES) - Finance Code 001 and "Fundação de Apoio à Pesquisa do Estado do Rio de Janeiro" (FAPERJ).

\section{REFERENCES}

Bencina D, Tadina T, Dorrer D. Natural infection of ducks with Mycoplasma synoviae and Mycoplasma gallisepticum and Mycoplasma egg transmission. Avian Pathology 1988;17:441-449. 
Magalhães BSN, Pereira VLA,

Machado LS, Dias TS, Balthazar DA,

Barreto ML, Troccoli F, Cunha NC,

Nascimento ER, Almeida FM, Almosny NR

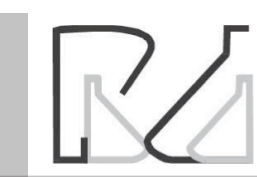

Occurrence of Avian Mycoplasmas in Free-Living Muscovy-Ducks (Cairina Moschata)
Carvalho AM, Andrade MA, Linhares GFC, Jaime VS. Pesquisa de Mycoplasma em aves da família Psittacidae mantidas em diferentes cativeiros no Brasil Central. Pesquisa Veterinária Brasileira 2017;37:1159-1164.

Downs J, Loraamm R, Anderson J, Perry J, Bullock J. Habitat use and behaviours of introduced muscovy ducks (Cairina moschata) in urban and suburban environments. Suburban Sustainability 2017;5(1).

Elhamnia F, Banani M, Shokri GR, Pourbakhsh SA, Ashtari A. Detection of Mycoplasma synoviae infection in broiler breeder farms of Tehran province using PCR and culture methods. Archives of Razi Institute 2010;65(2):75-81.

Goldberg DR, Samuel MD, Thomas CB, Sharp P, Krapu GL, Robb JR, et al. The occurrence of mycoplasmas in selected wild north american waterfowl. Journal of Wildlife Diseases 1995;31:364-371.

Gomes AM, Costa LL, Vilela DR, Marques MVR, Carvalhaes AG, Marin SY, et al. Detection of Mycoplasma gallisepticum in dead captive psittacines in Belo Horizonte, Brazil. Brazilian Journal of Poultry Science 2010;12:75-78.

Ivanics E, Glávitis R, Takács G, Molnár E, Bitay Z, Meder M. An outbreak of Mycoplasma anatis infection associated with nervous symptoms in large-scale duck flocks. Zentralblatt Veterinarmedizin Reihe B 1988;35:368-378.

Lauerman LH, Hoerr FJ, Sharpton AR, Shah SM, van Santen VL. Development and application of a polymerase chain reaction assay for Mycoplasma synoviae. Avian Diseases 1993;37:829-834.

Michiels T, Welby S, Vanrobaeys M, Quinet C, Rouffaer L, Lens L, et al. Prevalence of Mycoplasma gallisepticum and Mycoplasma synoviae in commercial poultry, racing pigeons and wild birds in Belgium. Avian Pathology 2016;45:244-252.

Nascimento ER do, Nascimento M da GF do, Vasconcelos MP de, Barreto $\mathrm{ML}$, Almeida JF de, Campos CA de M, et al. Aprimoramento da PCR para Mycoplasma gallisepticum pelo encurtamento do "amplicon" e ajustes no processamento da amostra. Acta Scientiae Veterinarie 2005a;33:297.
Nascimento ER, Pereira VL de A. Micoplasmoses. In: Fabio J, Rossini L, editors. Doenças das aves. $2^{\text {nd }}$ ed. Campinas: FACTA; 2009.

Nascimento ER, Pereira VLA, Nascimento MGF, Barreto ML. Avian mycoplasmosis update. Brazilian Journal of Poultry Science 2005b;7:1-

Razin S, Yogev D, Naot Y. Molecular biology and pathogenicity of mycoplasmas. Microbiology and Molecular Biology Reviews 1998;62:1094-1156

Sambrook J, Russell DW. Purification of nucleic acids by extraction with phenol: chloroform. CSH Protocols 2006;(1):pdb.prot4455

Silva LTR, Santos SB, Rameh-de-Albuquerque LC, Siqueira DB, Amorim MMR, Almeida JC, et al. Detecção molecular e isolamento de Mycoplasma spp. em psitacídeos no estado de Pernambuco, Brasil. Arquivo Brasileiro de Medicina Veterinária e Zootecnia 2016;68:113118.

Solomon P, Bisschop S, Joannis TM, Shittu I, Meseko C, Sulaiman L, et al. Phylogenetic analysis of Newcastle disease viruses isolated from asymptomatic guinea fowls (Numida meleagris) and Muscovy ducks (Cariana moscata) in Nigeria. Tropical Animal Health and Production 2013;45:53-57.

Timenetsky J, Santos LM, Buzinhani M, Mettifogo E. Detection of multiple mycoplasma infection in cell cultures by PCR. Brazilian Journal of Medical and Biology Research 2006;39:907-914.

Umar S, Munir MT, Ur-Rehman Z, Subhan S, Azam T, Shah MAA Mycoplasmosis in poultry: update on diagnosis and preventive measures. World's Poultry Science Journal 2017;73:17-28.

Uphoff CC, Drexler HG. Comparative PCR analysis for detection of mycoplasma infections in continuous cell lines. In Vitro Cellular \& Developmental Biology - Animal 2002;38:79-85 